\title{
Saladin and the Ayyubid Campaigns in the Maghrib
}

\section{Saladino y las campañas ayyubíes en el Magreb}

\author{
Amar Baadj \\ University of Toronto, Canada
}

\begin{abstract}
Este artículo trata sobre la conquista de Libia y Túnez por Saladino (Șalāḥ al-Dīn) y los Ayyubíes en las décadas de 1170 y 1180 . En primer lugar se presenta una reconstrucción de las campañas dirigidas por los mamelucos ayyubíes Sharaf al-Dīn Qarāqūsh e Ibn Qarātikīn en Libia y de la guerra entre los almohades y los Ayyubíes en Ifrīqiya (Túnez) basada en fuentes primarias relevantes. A continuación se estudia en qué medida Saladino fue el responsable de estas expediciones militares y, finalmente, se discute el motivo de dichas expediciones. Se llega a la conclusión de que Saladino y sus emires invadieron el Magreb con el fin de controlar los puntos septentrionales de los ejes oriental y central de las rutas comerciales que cruzaban el Sahara y con esto lograr tener acceso al oro de África Occidental que pasaba a lo largo de estas rutas. Esto ocurrió en un momento en que había una gran escasez de metales preciosos en Egipto y Saladino necesitaba efectivo para pagar sus guerras con los cruzados en Palestina.
\end{abstract}

Palabras clave: Almohades; Ayyubíes; Saladino; Sharaf al-Dīn Qarāqūsh; comercio transsahariano; oro.
This article concerns the conquest of Libya and Tunisia by Saladin (Salāh al-Dīn) and the Ayyubids in the 1170 s and 1180 s. First it presents a reconstruction of the campaigns conducted by the Ayyubid mamlūks Sharaf al-Dīn Qarāqūsh and Ibn Qarātikinn in Libya and the conflict in Ifriqiya (Tunisia) between the Almohads and the Ayyubids based on the relevant primary sources. Then the extent to which Saladin was responsible for these military expeditions is considered and finally the issue of the motive behind them is discussed. It is concluded that Șalāh al-Dīn and his amirs invaded the Maghrib in order to control the northern termini of the eastern and central axes of the trans-Saharan trade routes, thereby gaining access to the West African gold which passed along these routes. This occurred at a time when there was a great shortage of precious metals in Egypt and Saladin was in need of cash to pay for his wars with the Crusaders in Palestine.

Key words: Almohads; Ayyubids; Saladin; Sharaf al-Dīn Qarāqūsh; Trans-Saharan trade; Gold.

Many works have been written about the life and times of Șalāḥ alDin which focus justifiably on his struggle against the Crusaders in Bilād al-Shām. The history of Șalāḥ al-Dīn's involvement in Maghribī affairs is not very well-known. In the 1170s two Ayyubid amirs, Sharaf 
al-Dīn Qarāqūsh and Ibn Qarātikīn, established control over Cyrenaica, the Libyan oases and Tripolitania. In the early 1180s Qarāqūsh outmaneuvered Ibn Qarātikin to become the undisputed leader of Ayyubid forces in the west. He entered into direct conflict with the Almohads and conquered most of Tunisia before he was finally defeated by the Almohad caliph al-Manșūr at the end of the decade.

This episode raises two major questions. First of all what was the nature of Qarāqūsh's relation with Șalāḥ al-Dīn and the Ayyubid state? Secondly what were the motives behind the invasion of Libya and Ifrìqiya by Ayyubid forces? In this paper we will first endeavor to reconstruct the course of the Ayyubid campaigns in the west making use of all of the available primary sources including the important chronicle by Ibn Taqī al-Dìn which has been ignored by many of the modern scholars such as Mūsā, 'Inān, Thiry, and Mouton. ${ }^{1}$ Then we will take up the question of Qarāqūsh's relation with Șalāh al-Dīn and the Ayyubids to determine whether he was an independent warlord or a vassal of the latter. Finally we will examine the possible reasons for the invasion of Libya and Ifrīqiya by Qarāqūsh and propose our own thesis.

In 562/1169 Șalāh al-Dīn succeeded his uncle Shīrkūh as commander of the Zankid expeditionary force in Egypt which was comprised of several thousand Kurdish and Turkic horsemen and which contained many members of the Ayyubid clan who would later hold important commands under Șalāḥ al-Dīn. Though Șalāḥ al-Dīn was a devout Sunnī and a vassal of the powerful ruler of Syria Nūr al-Dīn Zankī, he also occupied the post of vizier under al- ${ }^{\circ}$ Adid, the last Fatimid caliph. It was no secret that Șalāh al-Dīn hoped to disband the remaining Fatimid military units and fill the administration with his own followers. For this reason Fatimid loyalists, including the Black and Armenian regiments who had the most to lose if the new vizier were to see his military reforms through, rose up against Șalāh al-Dīn

${ }^{1}$ Ibn Taqī al-Dīn, Midmār al-haqā'iq wa-sirr al-khalā'iq; 'Inān, Dawlat al-islām fì lAndalus: 'așr al-Murābițīn wa-l-Muwahhidīn fì l-Maghrib wa-l-Andalus; Mouton, "La conquête de la Cyrénaïque et de la Tripolitaine par Qarâqûsh: initiative individuelle ou enterprise d'état?;" Mūsā, Dirāsāt fì tārīkh al-Maghrib al-islāmī, pp. 11-41; Thiry, Le Sahara libyen dans l'Afrique du Nord médiéval, pp. 249-91. To his great credit al-Ghannāy appears to be the first scholar who recognized the value of Ibn Taqi al-Din as a source for the career of Qarāqūsh. See al-Ghannāy, Marāji 'Aqīla, Suqūt dawlat al-Muwahhịidìn, pp. 187-226. 
and the Kurds. After fierce fighting in the streets of Cairo, the latter succeeded in ruthlessly quashing the rebellion. ${ }^{2}$

Now Șalāḥ al-Dīn became the de facto ruler of Egypt; his army was the only serious military force remaining in the country and the Fatimid caliph became a mere puppet in his hands. Al- ${ }^{-}$Adid died in 567/1171 but already during the course of this caliph's long and fatal illness Șalāh al-Din had ordered the substitution of his name for that of the orthodox Abbasid caliph in the Friday sermon. ${ }^{3}$ There remained the issue of Șalāh al-Dīn's relations with his overlord Nūr al-Dīn which had grown more troubled as the former increased in power and confidence. ${ }^{4} \mathrm{Ibn}$ al-Athìr suggests that Șalāḥ al-Dīn was reluctant to press too hard on the Crusaders at this stage because their presence provided a useful buffer against Nūr al-Dīn. ${ }^{5}$ He relates that in 567/1171 Șalāḥ al-Dīn besieged the key Crusader stronghold of Shawbak in what is now southern Jordan and reduced it to the brink of surrender when Nür al-Din hastened south from Damascus at the head of his own army, hoping to coordinate a joint campaign with Șalāh al-Dīn against the Crusaders. Șalāh al-Dīn's advisors urged him to break the siege and retire to Egypt, for if the Crusaders fell there would be nothing to stop Nūr al-Dīn from invading Egypt and removing the Ayyubids from power. Șalāh al-Dīn took their advice and he returned home under the pretext that he feared a Shīî uprising in Cairo. ${ }^{6}$

It was at this time that Salāh al-Dīn began sending expeditions to some of the lands surrounding Egypt. ${ }^{7}$ In 568/1172 his older brother Shams al-Dawla Tūrānshāh invaded Nubia and wreaked havoc throughout that land. In the following year Türānshāh led an expedition to Yemen while some Ayyubid forces stayed in Nubia until they were driven out in 571/1175. According to Ibn al-Athìr, Șalāh al-Dīn ordered the invasions of Nubia and Yemen because he was seeking a refuge to which he

2 Ibn al-Athīr, 'Izz al-Dīn, al-Kāmil fi l-tārìkh, pp. 18-19; al-Maqrīzì, Itti' āz al-hunafă' bi-akhbār al-a'imma al-Fātimìyin al-khulafă', vol. 3, pp. 311-313; Ibn Taghrībirdī, al-Nujūm al-żāhira fi mulūk Miṣr wa-l-Qāhira, vol. 5, pp. 348-349; Eddé, Saladin, pp. 52-57; Lev, Saladin in Egypt, pp. 81-84.

${ }^{3}$ Lev, Saladin in Egypt, pp. 81-84.

${ }^{4}$ Eddé, Saladin, pp. 78-82; Lev, Saladin in Egypt, pp. 94-97.

${ }^{5}$ Ibn al-Athīr, al-Kāmil, vol. 10, pp. 35-36; al-Maqrīiñ, al-Sulūk li-ma'rifat duwal alMulūk, vol. 1, pp. 153-154.

${ }^{6}$ Ibn al-Athīr, al-Kāmil, vol. 10, pp. 35-36; al-Maqrīzì, al-Sulūk, vol. 1, pp. 153-154.

7 Eddé, Saladin, pp. 73-78; Lev, Saladin in Egypt, pp. 97-101. 
could retire in the event that Nür al-Din invaded Egypt. ${ }^{8}$ We should bear in mind, however, that Ibn al-Athir was a well-known partisan of the Zankids. ${ }^{9}$ It is not surprising that he sought to portray Salāh al-Dīn as being duplicitous and disloyal in his dealing with Nūr al-Dīn Zankī.

A number of expeditions were made to the Maghrib beginning with Barqa followed by lands lying further west. The two commanders who are identified with these campaigns in the Maghrib are Sharaf al-Din Qarāqūsh and Ibrāhīm b. Qarātikīn. Both of these men were mamlūks of Taqī al-Dīn "al-Malik al-Muzaffar," the nephew of Șalāh al-Dīn. The chroniclers disagree on the year in which the Ayyubids began their westwards incursions as well as the motives behind them. Ibn al-Athir says that the invasion of the Maghrib commenced in 568/1172 though he does not ascribe a motive to it as he did with the campaigns to Yemen and Nubia. ${ }^{10}$ On the other hand, al-Tijāni and the historians who followed him such as Ibn Khaldūn and Ibn Ghalbūn state that the Ayyubid invasion of Libya was also motivated by the desire to establish a potential refuge in case Egypt fell to an invasion by Nūr al-Dīn. ${ }^{11}$

In some sources it is reported that Taqi al-Dīn, jealous of the military triumphs of his other Ayyubid relatives, had resolved to invade the Maghrib himself. He assembled an army near Alexandria for this purpose but in the end he did not march. Some accounts say that he feared the difficulties involved in an invasion of the west while others say that he was dissuaded by Salāh al-Dīn. Nonetheless a group of his soldiers, led by Qarāqūsh and Ibn Qarātikīn, disobeyed orders and "fled" to Libya where they commenced their career of conquest. This version cannot be taken seriously since it is a blatant attempt to absolve Șalāh al-Dīn and the Ayyubids of any responsibility for the doings of their subordinates in the Maghrib. ${ }^{12}$

The most likely version of events is given by al-Maqrīzì and Abū Shāma who depict the conquest of Libya as having occurred in stages.

${ }^{8}$ Ibn al-Athīr, al-Kāmil, vol. 10, pp. 45-46, 52.

${ }^{9}$ Mușțafā, al-Tārīkh al-'arabì wa-l-mu'arrikhūn, vol. 2, p. 114.

${ }^{10}$ Ibn al-Athìr, al-Kāmil, vol. 10, p. 47.

11 Al-Tijānī, Rihlat al-Tijānī, pp. 111-112; Ibn Khaldūn, al-'Tbar wa-dīwān al-mubtada' wa-l-khabar, $\dot{6}$, p. 255; Ibn Ghalbūn, al-Tadhkār fi man malaka Tarāblūs wa-mā kāna bihā min al-akhbār, p. 69.

12 Ibn Wāṣil, Mufarrij al-kurūb fi akhbār Banī Ayyūb, vol. 2, pp. 180-182; Ibn alAthīr, al-Kāmil, vol. 10, pp. 139-140; Abū Shāma, Kitāb al-Rawdatayn fi akhbār al-dawlatayn, vol. 2, p. 274, vol. 3, pp. 164-170; al-Tijānī, Rihlla, p.112. 
According to al-Maqrīzī the first campaign was in 568/1172 when Qarāqūsh invaded Cyrenaica. ${ }^{13}$ It appears that the conquest of Cyrenaica had already been completed before Nūr al-Dīn Zankī's death in $569 / 1174$ since there is a letter from Nūr al-Dīn to the Abbasid caliph in which the former includes Cyrenaica among his possessions (Șalāh al-Dīn was still in theory Nūr al-Dīn's vassal). ${ }^{14}$ In 571/1175 Qarāqūsh captured the oasis of Awjila and installed a deputy there. ${ }^{15}$ It appears from al-Maqrīzī's account that Qarāqūsh made annual expeditions against the Libyan oases throughout the 1170s at the end of which he always returned to Egypt. ${ }^{16}$ Abu Shäma reports that after capturing Awjila in 571/1175 Qarāqūsh announced that he was returning to Egypt to raise a fresh army. ${ }^{17}$ This would have been impossible if Qarāqūsh and his men were renegades who did not take orders from the Ayyubids as claimed by al-Tijānī. In fact al-Tijānī contradicts himself because he also records that whenever Qarāqūsh captured a city he had the names of Salāh al-Dīn and Taqi al-Dīn recited in the Friday sermon, hardly the behavior of a deserter. ${ }^{18}$

After completing the conquest of Cyrenaica and the eastern Libyan oases, Qarāqūsh made his way south to Zawila, capital of Fezzan. At this time Zawìla was ruled by an Ibāẹi Berber dynasty known as the Banū al-Khatṭāb. It was an immensely wealthy city due to its key position along the trans-Saharan trade routes. Qarāqūsh tortured to death the last sultan of the Banū al-Khattāa and took a great amount of loot. ${ }^{19}$ In 573/1176-77 Qarāqūsh linked up with the other Ayyubid commander in Libya, Ibn Qarātikīn, and together they captured an oasis called alRuḥhān (perhaps a misreading of Waddān?). Then they marched west and took Ghadāmis. ${ }^{20}$

In 575/1180 we find Qarāqūsh and Ibn Qarātikīn at odds with one another in Tripolitania. In addition to their Kurdish and Turkish troops each leader had gathered allies from among the Sulaymī Arab tribes. Qarāqūsh began a long lasting association with Ḥamīd b. Jāriya, chief

${ }_{13}$ Al-Maqrīīi, al-Sulūk, vol. 1, p. 153.

${ }^{14}$ Ibn Wāṣil, Mufarrij al-kurūb, vol. 1, p. 235.

15 Abū Shāma, Kitāb al-Rawdatayn, vol. 2, pp. 274-75.

16 Al-Maqrīīi, al-Sulūk, vol. 1, pp. 153, 171, 174-175.

${ }^{17}$ Abū Shāma, Kitāb al-Rawdatayn, vol. 2, p. 275.

18 Al-Tijānī, Rihla, pp. 111-113.

19 Al-Tijānī, Riḥla, pp. 111-113.

20 Al-Maqrīzī, al-Sulūk, vol. 1, pp. 175-176. 
of a powerful Sulaymī tribe called the Dabbāb. The two Ayyubid mam$l \bar{u} k$ s clashed at a wadi in Jabal Nafūsa called Araqtịn; Ibn Qarātikīn won the day through a clever ruse. Qarāqūsh regrouped his forces and eventually he came to terms with Ibn Qarātikin. It was agreed that each leader would take half of the villages of Jabal Nafüsa as his sphere of influence. Qarāqūsh established a fortress in his area of Jabal Nafūsa called Umm al-'Izz where he left his family and treasure under guard. Then he marched west to continue his conquests. ${ }^{21}$

In 576/1181 he campaigned in Jabal Dammar (now Mațmāta in southeastern Tunisia by the Libyan border). The inhabitants of this region were Ibādī Berbers whose mountain strongholds appeared almost inaccessible to outsiders. Qarāqūsh and his men succeeded in capturing the most important of these citadels after long and harrowing sieges of which we find detailed accounts in the chronicle of Ibn Taqi al-Dīn who was personally acquainted with some of the participants. After subduing the tribes of Jabal Dammar Qarāqūsh was ready to advance into the heart of Ifriquiya (modern Tunisia). ${ }^{22}$

In the summer of 577/1182 Qarāqūsh attempted to capture Qafșa but he was thwarted by the city's pro-Almohad faction. Then he headed further north and besieged al-Sikka near Qayrawān. The Almohads, who seem to have ignored the Ayyubid presence west of Barqa up to this point, finally decided to take action and they dispatched an army of 10,000 cavalry and an equal number of infantry against Qarāqūsh. The latter, after having received substantial reinforcements from several Arab tribes, inflicted a crushing defeat on the Almohads. He captured many high-ranking prisoners including the chief judge of Ifriqiya and the head of the provincial treasury who were ransomed for high sums of money. He demanded and received the districts of Sūs and alMahdiya as $i q t \bar{a}$ 's. Then al-Sikka finally capitulated to his forces. ${ }^{23}$

Qarāqūsh was not able to enjoy his success for long. He received word that Ibn Qarātikīn, acting on rumours of Qarāqūsh's death in battle, had broken his truce and occupied Qarāqūsh's portion of Jabal Nafūsa. He also captured Qarāqūsh's family and treasury in Umm al- ${ }^{\circ}$ Izz. ${ }^{24}$ Qarāqūsh hurried back to Libya with his followers and pur-

${ }^{21}$ Ibn Taqī al-Dīn, Midmāar, pp. 34-38.

${ }_{22}$ Ibn Taqī al-Dīn, Midmāar , pp. 53-57; Abū Shāma, Kitāb al-Rawdatayn, vol. 3, p. 49.

${ }^{23}$ Ibn Taqī al-Dīn, Midmāàr, pp. 68-70; Abū Shāma, Kitāb al-Rawḍtayn, vol. 3, p. 66.

${ }^{24}$ Ibn Taqī al-Dīn, Mị̀mār , pp. 68-70; Abū Shāma, Kitāb al-Rawḍdatayn, vol. 3, p. 66. 
sued Ibn Qarātikīn across Jabal Nafūsa from one stronghold to the next. Finally he surrounded him in an imposing fortress called Tinzalt which was located in the middle of a great wadi and reputed to be unassailable. With the aid of specially enhanced siege engines Qarāqūsh succeeded in capturing the place. He granted Ibn Qarātikin safe conduct to Tripoli (which was then ruled by an Almohad governor) on the condition that he sail from there to Egypt. Instead Ibn Qarātikin sailed to Tunis and later made his way to Marrakech where he took service with the Almohads. ${ }^{25}$ It was probably not long after these events that Qarāqūsh captured Tripoli since al-Tijānī records that he once saw in Tripoli an original decree issued by Qarāqūsh concerning the expansion of certain properties in that city that was dated 579/1183-84. ${ }^{26}$

After re-establishing control over Tripolitania Qarāqūsh headed back to Tunisia in the same year. He tried and failed to capture Qābis though he did manage to take over some strongholds in the interior. Then he invaded Nafzāwa (in southwestern Tunisia south of the Jarīd) where he defeated the local Berber chiefs and captured their strongholds. ${ }^{27}$ In 580/1184-85 Qarāqūsh invaded the fertile and populous peninsula of Bāshū (Cap Bon, located south of Tunis) which he and his men plundered for a full three months. ${ }^{28}$

In the previous year reinforcements had reached Qarāqūsh from Egypt. An Ayyubid officer named Shujāe al-Dīn Ibn Shakl arrived in the west at the head of 400 Kurdish and Turkish cavalry. Qarāqūsh had assigned Ibn Shakl and his men 120 villages near Suwayqa in eastern Tripolitania as $i q t \bar{a}$ 's for their maintenance. While Qarāqūsh was preoccupied with the invasion of Bāshū, Ibn Shakl plotted against him with the chief of the Banū 'Awf, a Sulaymì Arab tribe. Unfortunately for Ibn Shakl, the vast majority of the Turkish and Kurdish troops remained loyal to Qarāqūsh who handily defeated Ibn Shakl and the Banū 'Awf at the battle of Sardāniya near Qayrawān. ${ }^{29}$ After the battle Qarāqūsh reconciled with Ibn Shakl and the Banū 'Awf and he accepted them back into his fold. Then, accompanied by a great host of allied Arabs, Qarāqūsh made his boldest raid yet into the heart of Almohad

${ }^{25}$ Ibn Taqī al-Dīn, Midmāer, pp. 70-72.

${ }^{26}$ Al-Tijānī, Rihla, p. 114.

27 Ibn Taqī al-Dīn, Midmār r, pp. 167, 202.

${ }^{28}$ Ibn Taqī al-Dīn, Midmāer, pp. 202-203.

29 Ibn Taqī al-Dīn, Mị̣̂ār , pp. 167-168, 202-204. 
Ifriqiya. During this expedition he reached the walls of Tunis and amassed more booty than any of his previous campaigns had yielded. ${ }^{30}$

In 581/1185-86 'Alī b. Ghāniya arrived in Ifríqiya with his followers. The Banū Ghāniya were a branch of the Almoravid (Murābitīi ruling family that held out in the Balearic Islands where they established an independent principality after the fall of al-Andalus and the Maghrib to the Almohads in the middle of the twelfth century A.D. ${ }^{31}$ In 580/1184 the amir of the Banū Ghāniya, 'Alì, led a fleet and expeditionary force from Majorca to the port of Bijāya in al-Maghrib alAwsat (Algeria) which he seized from the Almohads. In subsequent campaigns he conquered a large swath of territory from Algiers and Milyāna in the west to Constantine in the east. Within less than a year he lost all of his new conquests in the face of a determined Almohad counterattack. 'Ali and his remaining troops fled eastwards to territory that was under the control of Qarāqūsh seeking an alliance with the latter against the Almohads. ${ }^{32}$

It should be noted that both the Ayyubids, whom Qarāqūsh served, and the Almoravids, whose claims were represented by the Banu Ghāniya, recognized the religious and moral authority of the Abbasid caliphs in Baghdad. The Almohads, on the other hand, had claimed the title of caliph for themselves thus they did not recognize the legitimacy of the Abbasids. This meant that there was common ideological ground for an Ayyubid-Almoravid alliance against the Almohads. Qarāqūsh was enthusiastic about 'Alī b. Ghāniya's proposal for such an alliance. The two leaders sent a delegation to Baghdād that included 'Alī's son and personal secretary in order to gain the [symbolic] approval of the Abbasid caliph al-Nāșir (575/1180-622/1225). The latter accorded to 'Alī b. Ghāniya all of the privileges that his Almoravid ancestors had enjoyed. He authorized Șalāh al-Dīn al-Ayyūbī, who was technically his vassal, to assist the Banū Ghāniya in any way possible. Șalāḥ al-

${ }^{30}$ Ibn Taqī al-Dīn, Midmār $r$,pp. 203-204.

31 The classic account of the revolt of the Banū Ghāniya is A. Bel's Les Benou Ghânya. For more modern treatments that take into account sources discovered after Bel wrote his work see the relevant chapters in Huici Miranda, Historia Politica del Imperio Almohade; 'Inān, Dawlat al-islām fì l-Andalus, vol. 2.

${ }^{32}$ Ibn al-Athīr, al-Kāmil, vol. 10, pp. 128-127, 137; al-Marrākushī, al-Mu 'jib fì talkhīs akhbār al-Maghrib, pp. 346-347; Ibn 'Idhārī, al-Bayān al-Mughrib fì akhbār al-Maghrib wa-l-Andalus: qism al-Muwahhidìn, pp. 175-183; Ibn Khaldūn, al-'Tbar, vol. 6, pp. 254255, 326-327. 
Dīn for his part ordered Qarāqūsh to cooperate with the Banū Ghāniya in restoring the Abbasid da $w a$ to Ifriqiya and the Maghrib. ${ }^{33}$

Qarāqūsh and 'Alī b. Ghāniya campaigned together in the Jarīd (a region of oases and salt-lakes in southwestern Tunisia) and captured its chief cities including Nafța, Tūzur, and Qafșa. The two warlords agreed on a division of all future conquests: to the Banū Ghāniya would go all lands west of Annaba while Qarāqūsh and the Ayyubids were confirmed in their possession of all the lands lying to its east. By 582/1186 Qarāqūsh was at the height of his power. He controlled Cyrenaica, Fezzan, Tripolitania, and all of Ifriqiya save for the ports of Tunis and al-Mahdiya, the last bastions of Almohad rule in the east. He counted as his allies all of the major tribes of the Banū Sulaym as well as 'Alī b. Ghāniya and his followers. ${ }^{34}$

From the perspective of the Almohads the situation was quite dire and it demanded the intervention of the caliph Abū Ya'qūb al-Mansūr himself. In 582/1186 Al-Manșūr departed Fez at the head of a force that contained 20,000 cavalry according to Ibn al-Athir and he reached Tunis in the same year. ${ }^{35} \mathrm{He}$ sent a detachment south under the command of the governor of Ifrīqiya, Abū Yūsuf b. Abī Hafṣ, to engage Qarāqūsh. The encounter between the two sides occurred at the plain of ${ }^{~} \mathrm{Umra}$ near Qafșa in the summer of 583/1187. The Almohads were in a poor state; their troops were wracked by thirst and exhaustion after a long and difficult forced march while the commanders incessantly quarreled. As a consequence they suffered a severe defeat at the hands of Qarāqūsh and 'Alī b. Ghāniya who slaughtered their captives without pity. ${ }^{36}$

The caliph al-Manșür spent the next few months drilling, equipping, and reinforcing his army in Tunis in preparation for a second encounter with Qarāqūsh. In fall of the same year he led the army out in person, proceeding first to Qayrawān and then to a town called Hamma in the Jarid. In the battle of Hamma the Almohads thoroughly routed the enemy coalition. Qarāqūsh and 'Alī b. Ghāniya fled in the direction of the desert. Rather than pursue them al-Manșūr focused on besieging Qābis and Qafșa. In the winter of 583/1187 the caliph returned to Tunis where he reordered the affairs of Ifriqiya and appointed his brother as

33 Al-Tijānī, Rihla, p. 162; Ibn Khaldūn, al-'Ibar, vol. 6, pp. 254-256.

${ }^{34}$ Ibn Taqī al-Dīn, Midmāer, pp. 229-230.

35 Ibn al-Athīr, al-Kämil, vol. 10, p. 137.

${ }^{36}$ Ibn 'Idhārī, al-Bayān, pp. 188-189. 
its governor. Then in the spring of 584/1188 he departed for Marrakech with the bulk of his army. ${ }^{37}$

'Alī b. Ghāniya died shortly after the Almohad reconquest of Ifriqiya and he was succeeded by his brother Yahyā as leader of the Banū Ghāniya. ${ }^{38}$ Qarāqūsh and his troops entered the service of the Almohad governor in Tunis from 583/1187 to 586/1190. Then he and his followers turned renegades capturing Qābis and Tripoli from the Almohads and entering into an alliance with Yahyā b. Ghāniya who was based in Tripolitania at that time. ${ }^{39}$ The relationship soon turned sour and Qarāqūsh found himself in conflict with Yahyā, who was an even more formidable leader than his predecessor 'Alī. Yahyā inflicted a crushing defeat on Qarāqūsh at a place called Muhsin in the vicinity of Tripoli. ${ }^{40}$ Qarāqūsh and his remaining Turkish and Kurdish troops fled to Jabal Nafüsa and eventually they established themselves at the oasis of Waddān in the Libyan desert. Yahyā left them alone for the time being as he focused all of his efforts on the struggle against the Almohads. It was only in 609/1212 that Yahya turned his attention to Qarāqūsh once again. He besieged Qarāqūsh in his stronghold in Waddān until he was finally forced to surrender. Then the old mamlūk was led out and executed along with his son. Yahyā continued his struggle against the Almohads until his death from old age in the early $1230 \mathrm{~s} .{ }^{41}$

In the late 1180s, following the defeat of Qarāqūsh and his allies at the hands of the Almohads, Salāh al-Dīn entered into negotiations with the Almohad caliph al-Manșūr. Faced with the unprecedented threat of the Third Crusade in Bilād al-Shām, Șalāh al-Dīn could not afford to commit men and resources to the Maghribi front any longer nor did he want to further provoke the Almohad caliph who was still the most powerful Muslim sovereign in the Mediterranean Basin. Copies of two letters from Șalāh al-Dīn to the caliph al-Manșūr have survived: one is preserved in al-Qalqashandi's Subh al-A'shā and the other in Abū Shāma's Al-Rawdiatayn fì Akhbār al-Dawlatayn. ${ }^{42}$ Gaudefroy-Demom-

${ }^{37}$ Ibn 'Idhārī, al-Bayān, pp. 190-197; al-Tijānī, Riḥla, pp. 138-139, 236-237; al-Ḥimyārī, al-Rawd al-mi'târ fi khabar al-aqtāar, pp. 414-415.

${ }_{38}$ Al-Tijānī, Rih̆la, p. 162; Ibn Khaldūn, al-'Tbar, vol. 6, p. 257.

39 Al-Tijānī, Rihhla, p. 104; Ibn Khaldūn, al-'Ibar, vol. 6, p. 257.

40 Al-Tijānī, Rihhla, pp. 147, 243-245; Bel, Les Benou Ghânia, pp. 93-99.

${ }^{41}$ Al-Tijānī, Riḥla, pp. 110-111; Bel, Les Benou Ghânia, pp. 155-157.

${ }^{42}$ Abū Shāma, Kitāb al-Rawḍatayn, vol. 4, pp. 115-124; al-Qalqashandī, Șubh ala'shä fi kitäbat al-inshā, vol. 6, pp. 526-530. 
bynes believes that the first letter was composed in the autumn of $585 / 1189$ and the second letter in 586/1190. ${ }^{43}$ Abū Shāma has also preserved the text of a letter containing special instructions for the Ayyubid envoy to the Almohad court that was composed by the pen of al-Qâdī al-Fādili (d. 596/1199), Șalāh al-Dīn's great vizier. ${ }^{44}$

It is important to note the context of these letters. In 585/1189 the Crusaders commenced the siege and naval blockade of the Muslimheld port of Acre. ${ }^{45}$ Salāh al-Dīn's army in turn surrounded the Crusader army which was now sandwiched between the defenders and the Ayyubid army. Nonetheless the position of the Crusaders remained strong because of their overwhelming superiority over the Ayyubids at sea which allowed them to continue the naval blockade of Acre and reinforce the besieging army. In the two official letters to the Almohad court Șalāh al-Dīn recounts his recent achievements including the liberation of Jerusalem. Then he describes the massive Christian response of the Third Crusade which brought fresh armies and several European monarchs to Palestine. He notes in particular the dire circumstances of Acre and he asks the Almohad caliph to send a fleet in order to break the blockade of its port by the Christian armada. ${ }^{46}$

The secret letter of instructions is of more interest to us. In this letter the vizier advises his ambassador how to respond if the Almohads bring up the subject of Qarāqūsh and Yūzbā [Ibn Qarātikīn?] and their activities in the Maghrib. ${ }^{47} \mathrm{He}$ directs him to tell the Almohads that the latter are not from among the amirs and officers of the state and their followers are a motley rabble who come and go. He adds "God forbid that 289, 297.

43 Gaudefroy-Demombynes, "Une lettre de Saladin au calife Almohade," vol. 2, pp.

44 Abū Shāma, Kitāb al-Rawdatayn, vol. 4, pp. 111-114.

45 On the siege of Acre see Eddé, Saladin, pp. 291-301; Ehrenkreutz, "The Place of Saladin in Mediterranean Naval History," pp. 112-15.

${ }^{46}$ Abū Shāma, Kitāb al-Rawḍatayn, vol. 4, pp. 115-120; al-Qalqashandī, Subh, vol. 6, pp. 526-530.

47 The identity of Yūzbā is not clear. Gaudefroy-Demombynes believes that he and Ibn Qarātikīn were the same person; he suggests that Yūzbā was Ibn Qarātikīn's Armenian name. Mouton believes that they were two separate Ayyubid amirs. According to Mouton, Ibn Qarātikin arrived in Libya in the 1170s and he was captured and killed by the Almohads in 583/1187. Yūzbā was another Ayyubid mamlūk who led a contingent from Egypt to Ifrīqiya in 582/1186 to reinforce Qarāqūsh. Approximately three years later he was captured by the Almohads whom he later served. See Gaudefroy-Demombynes, "Une lettre de Saladin,” pp. 290-291; Mouton, “La conquête de la Cyrénaïque,” p. 69, note 24. 
we would command a criminal to sow mischief in the world!"48 In effect, the Ayyubid leadership attempted to wash its hands of any responsibility for the affair of Qarāqūsh and Ibn Qarātikīn.

Although the Almohads received the Ayyubid delegation honorably and hospitably and showered them with gifts the hope for aid did not materialize and no Almohad squadrons were sent to the eastern Mediterranean. ${ }^{49}$ Despite the efforts of Șalāh al-Dīn, Acre finally fell to the Crusaders in 587/1191. Various explanations have been put forth as to why the Almohads did not assist Șalāh al-Dīn. Abū Shāma says that they did not send ships because they were offended by the Ayyubid envoy's failure to address their caliph as amir al-mu'minin (Commander of the Faithful) but Gaudefroy-Demombynes doubts this. ${ }^{50}$ Some modern scholars have suggested that al-Manșür could not spare the ships and men that Șalāh al-Dīn requested because he was preoccupied with the struggle against the Christian kingdoms in the Iberian Peninsula. ${ }^{51}$ We believe that the true purpose of the negotiations between Șalāḥ al-Dīn and al-Mansūur was to bring a formal end to hostilities between the Ayyubids and Almohads and to demarcate their respective spheres of influence. The Almohads were preoccupied with affairs in al-Andalus and the caliph could not afford to be absent in the east for extended periods as had occurred when he marched to Ifrīqiya to subdue Qarāqūsh. Likewise, Șalāh al-Dīn could no longer spare men or money for western adventures because he was hard-pressed in Syria by the forces of the Third Crusade. Thus Șalāh al-Dīn abandoned his alliance with the Banū Ghāniya and recognized Almohad possession of Ifriqiya and Tripolitania. After the conclusion of peace with the Almohads we hear of no further Maghribī expeditions by Șalāḥ al-Dīn and his Ayyubid successors.

Modern scholars have various opinions on the nature of Qarāqūsh's relations with the Ayyubids during the years when he dominated Libya and Ifriquiya. Mūsā attributes the invasion of the western lands to the

48 Abū Shāma, Kitāb al-Rawḍtatayn, vol. 4, p. 114.

49 Abū Shāma, Kitāa al-Rawḍatayn, vol. 4, pp. 119-120; Ibn 'Idhārī, al-Bayān, pp. 209-212.

${ }^{50}$ Abū Shāma, Kitāb al-Rawdatayn, vol. 4, p. 120; Gaudefroy-Demombynes, "Une lettre de Saladin," pp. 300-302.

${ }^{51}$ Gaudefroy-Demombynes, "Une lettre de Saladin," pp. 295-296; 'Inān, Dawlat alislām fì l-Andalus, vol. 2, p. 185; Khalaf Allāh, al-'Alāqāt bayna l-khilāfa al-Muwahhịì̄ya wa-l-Mashriq al-islāmī: 1130-1529/564-936, pp. 166-167. 
personal ambition of Qarāqūsh and other amirs and he rejects the possibility that there was an Ayyubid plan of conquest. ${ }^{52}$ Mouton believes that the initiative for the western campaigns came from the Ayyubids themselves. He even suggests that Libya and Ifriqiya formed a single province in the 1170s and 80s administered by Qarāqūsh in the manner of a typical Ayyubid wāli or governor. ${ }^{53}$ Unfortunately Mouton and Mūsā appear to be unaware of Ibn Taqī al-Dīn's work which furnishes us with the most convincing evidence for direct Ayyubid involvement in the invasion of Libya and the war with the Almohads. Al-Ghannāy and al-Sāhilī, who are aware of the importance of Ibn Taqī al-Dìn's account, conclude that Șalāh al-Dīn and his advisors planned and directed the invasion of Maghrib in order to secure Egypt's western frontier and forestall an Almohad invasion, an idea to which we will return below. ${ }^{54}$

We believe that the primary sources strongly support the notion that Șalāh al-Dīn ordered the invasion of Libya and Ifrīqiya by his subordinates Qarāqūsh and Ibn Qarātikin and that their conquests in the west had Șalāḥ al-Dīn's material and moral support. It has already been mentioned that according to al-Maqrīzì, Qarāqūsh returned to Egypt several times in the 1170s presumably to recruit fresh troops and gather supplies; needless to say this would have been impossible if he were really a fugitive from the sultan's authority as was implied in the written instructions for Șalāh al-Dīn's envoy to the Almohads. ${ }^{55}$ Al-Tijānī says that Qarāqūsh had the names of Șalāh al-Dīn and al-Malik al-Muẓaffar inserted into the Friday sermon in every town that he conquered. ${ }^{56}$ There is also Ibn Khaldūn's account of the joint embassy of Qarāqūsh and 'Alī b. Ghāniya to the Abbasid caliph who called on Salāh al-Dīn to support the Banū Ghāniya in their struggle against the Almohads. ${ }^{57}$

The best evidence of Șalāh al-Dīn's personal responsibility for the western expedition and the war on the Almohads can be found in the pages of Ibn Taqi al-Dīn's chronicle. He relates that the Ayyubids sent Ibn Shakl with 400 Kurds and Turks to reinforce Qarāqūsh shortly after

${ }^{52}$ Mūsā, Dirāsāt, pp. 19- 23, especially 23.

${ }^{53}$ Mouton, "La conquête de la Cyrénaïque," p. 63.

${ }^{54}$ Al-Ghannāy, Suqūt, p. 203; al-Sāhilī, al-Tawajjuhāt al-siyāsīya li-l-dawla al-Ayyūbìya al-dākhilìya wa-l-khārijìya, pp. 142-43.

${ }_{55}$ Al-Maqrīzī, al-Sulūk, vol. 1, pp. 153, 171, 174-175.

56 Al-Tijānī, Rihla, pp. 112-113.

${ }^{57}$ Ibn Khaldūn, al-'Tbar, vol. 6, p. 256. 
the latter declared war on the Almohads and defeated their army in a pitched battle at al-Sikka in central Tunisia. ${ }^{58} \mathrm{He}$ also mentions the use of heavy siege equipment by Qarāqūsh against the fortresses in Jabal Nafüsa and Jabal Dammar. ${ }^{59}$ The Arab and Berber tribes with whom Qarāqūsh was allied had no experience in this branch of warfare. His siege technicians must have come from Ayyubid Egypt. Finally there is a passage in Ibn Taqī al-Dīn's history relating to the capture of Ibn Qarātikīn by Qarāqūsh which states that Qarāqūsh was ready to execute Ibn Qarātikin when his men protested and forced him to swear on the life of his lord Taqi al-Dìn "al-Malik al-Muzaffar" that he would not harm Ibn Qarātikīn. ${ }^{60}$ The credibility of Ibn Taqī al-Dīn's story is hardly in doubt because he was the son of al-Malik al-Muzaffar, Qarāqūsh's patron, and by his own account he was personally acquainted with many of the participants in Qarāqūsh's expedition. ${ }^{61}$ Against such evidence, the claim in al-Qāọi al-Fādil's letter to the Almohad court that Qarāqūsh, Ibn Qarātikīn, and their men were outlaws over whom the Ayyubids had no authority can hardly be taken seriously.

The question that must now be posed is why Șalāh al-Dīn saw fit to occupy Libya and Ifrìqiya and enter into a direct confrontation with the Almohads. Some of the chroniclers claim that he invaded Barqa out of fear of Nūr al-Dīn or because he sought food supplies to alleviate a famine in Egypt. ${ }^{62}$ These explanations are dubious because Barqa obviously did not have the agricultural capacity to feed a country as populous as Egypt. The claim that Șalāh al-Dīn invaded Barqa seeking a refuge from Nūr al-Dīn is rather weak. Ibn al-Athīr appears to have been the first medieval historian to argue that Șalāh al-Dīn was seeking a possible refuge from the Zankids outside of Egypt. But we must remember that Ibn al-Athïr was a Zankid partisan who expressed hostility towards Șalāh al-Dīn in his writing whenever there was a clash of interest between the Ayyubids and the Zankids. ${ }^{63}$ By claiming that Șalāh al-Dīn was contemplating flight to a remote foreign land due to his fear

${ }^{58}$ Ibn Taqī al-Dīn, Midmāer, pp. 68-70.

${ }^{59}$ Ibn Taqī al-Dīn, Midmārr, p. 69. Map 1: The Medieval Libyan Sahara.

${ }^{60}$ Ibn Taqī al-Dīn, Midmāer, pp. 71-72.

${ }^{61}$ Ibn Taqī al-Dīn, Midmāre, p. 54.

${ }^{62}$ Al-Tijānī, Rihla, pp. 111-112; al-Maqrīzī, al-Sulūk, vol. 1, p. 153.

${ }^{63}$ Muștafā, al-Tärīkh al-'Arabì, vol. 2, pp. 111-16; Ehrenkreutz, Saladin, p. 2; Lev, Saladin in Egypt, pp. 36-41. 
of facing Nūr al-Dīn, Ibn al-Athìr magnifies the power of the Zankid lord while casting Șalāh al-Dīn as a weak and duplicitous character. It is also important to note that Ibn al-Athìr mentions only Yemen and Nubia as possible destinations. The first person to suggest that Șalạ al-Dīn invaded Barqa in search of a refuge from the Zankids was alTijāni who wrote in Tunis in the late thirteenth century. It is highly unlikely that Barqa or anywhere else in Libya could have provided a viable long-term refuge for the Ayyubids who needed enough land to support an army of 14,000 Turkish and Kurdish cavalry. ${ }^{64}$ We must also remember that the supposed threat from Nūr al-Dīn disappeared with his death in 569/1174 while the campaign in the Maghrib continued for over a decade.

We now turn to the opinions of modern scholars on this matter. The western scholars have little to say about Șalāh al-Dīn's motives for invading Libya. Mouton does not discuss the issue in his short article. Thiry suggests in passing several possible causes for the Ayyubid conquests in Libya including refurbishing their treasury, establishing a refuge from Nūr al-Dīn, controlling trade routes for slaves and gold, obtaining wood for building ships, and threatening Norman Sicily. Unfortunately he does not explore the subject further and attempt to build a case for any of these ideas. ${ }^{65}$ Ehrenkreutz suggests that the westward expansion was linked to Șalāh al-Dīn's naval strategy. ${ }^{66}$ With control of the Mediterranean coastline up to Tunis Șalāh al-Dìn could obtain advance warning of Crusader reinforcements arriving by sea from the west. He would also have had access to timber from the mountains and he could recruit veteran Maghribì sailors for his fleet. An objection to this thesis is that the Ayyubids appear to have been far more interested in the Saharan oases than the Libyan coastline.

Al-Ghannāy and al-Sāhilī argue that the Almohads, like the earlier Fatimids, harbored the ambition of invading Egypt from the west in order to extend their caliphate and its $d a^{\prime} w a$ into the eastern half of the Islamic World. They believe that Șalāḥ al-Dīn had real fears of an Almohad attack on Egypt ${ }^{67}$ In their view Qarāqūsh's expedition was a

${ }^{64}$ For the size of Șalāh al-Dīn's army see Ehrenkreutz, Saladin, pp. 73-75.

${ }^{65}$ Thiry, "L'Égypte et le déclin de l'Afrique du Nord (XIe - XIIe siècles)," p. 244.

${ }^{66}$ Ehrenkreutz, "The Place of Saladin," p. 105.

${ }^{67}$ Al-Ghannāy, Suqūt, pp. 196-198; al-Sāhịilī, al-Tawajjuhāt, pp. 135-43. 
preventive measure to protect the western approaches to Egypt and create a buffer zone between the Ayyubid and Almohad empires. There are a few passages in the medieval sources which attribute a desire to conquer Egypt and the Mashriq to the early Almohad caliphs and it is on these excerpts that al-Sāhili has based her thesis. Ibn Jubayr, who visited Egypt during the early part of Șalāh al-Dīn's reign, remarks that the Ayyubid sultan had constructed a six mile long causeway west of Cairo in order to allow troops to move quickly across the cultivated land between Cairo and the desert during the flood season. This would allow him to meet any invading army that chose to approach Cairo from the direction of the western desert. Ibn Jubayr then remarks that "to the Egyptians, the construction of these bridges is a warning of a coming event, for they see in it an augury that the Almohades will conquer it and the eastern regions. ${ }^{"}{ }^{8}$ In other passages Ibn Jubayr claims that there was widespread expectation of an Almohad invasion amongst the Egyptian masses and the ulema and that many people welcomed such a possibility. ${ }^{69}$ An anecdote by the historian Ibn Abi Tayy (d. 630/1233) which has been preserved in Abū Shāma's Rawdatayn suggests that the second Almohad caliph, Yūsuf b. 'Abd al-Mu'min (558/1163-580/1184), was seen by contemporaries as the Muslim ruler who was most likely to liberate the Holy Land from the Crusaders. ${ }^{70}$ Al-Marrākushī says that Yūsuf's son and successor, the caliph alManșūr (580/1184-595/1199), told his followers "Egypt is a land of heresy and we shall be its purifiers." He adds that the caliph maintained the wish of conquering Egypt until his death. ${ }^{71}$

There are some serious objections that must be raised to this bold thesis. It is certainly possible that some Muslims in the east saw the Almohads as their potential saviors from the Crusaders and it would not be surprising if the caliphs Yūsuf and al-Manșūr, whose reigns marked the apogee of the Almohad dynasty, occasionally entertained the notion of eastward expansion. But there is no evidence that any practical steps were taken to transform these fantasies into reality. Conquest of Egypt

${ }^{68}$ Broadhurst, The Travels of Ibn Jubayr: a Medieval Spanish Muslim Visits Makkah, Madinah, Cities of the Middle East and Sicily, p. 45; Text in Ibn Jubayr, Rihlat Ibn Jubayr, pp. 27-28.

${ }^{69}$ Broadhurst, The Travels of Ibn Jubayr, pp. 73-74; Ibn Jubayr, Rihla, pp. 55-57.

70 Abū Shāma, Kitāb al-Rawdatayn, ed. Beirut, Dār al Jìl (reprint of Wādī al-Nīl ed., 1871), vol. 2, p. 85, cited by al-Sähilili, al-Tawajjuhàt, pp. 141-42.

${ }^{71}$ Al-Marrākushī, al-Mu'jib, p. 360. 
from the west in the manner of the Fatimid invasion would have necessitated the occupation of the entire Mediterranean coastline from Tripoli to Alexandria along with the establishment of bases, digging of wells, and stockpiling of supplies along the length of this route.

Mūsā has pointed out that the Almohads did not exercise even nominal control over any territory east of Tripoli. ${ }^{72}$ Our sources indicate that the Almohads paid little attention to their eastern frontier. It is telling that Qarāqūsh faced no opposition from the Almohads until he reached al-Sikka, located well within modern Tunisia, in 577/1188. ${ }^{73}$ Al-Tijānī remarks that when Qarāqūsh captured Tripoli from the Almohads the city had no garrison, weapons, or supplies for withstanding a siege. He adds that the reason for this lack of preparedness was that the inhabitants never expected an attack from the east. ${ }^{74}$ There is only one reference to an Almohad army operating in Tripolitania; this occurred in 602/1206 during the pacification of Ifriqiya by the caliph alNāṣir, many years after the death of Șalāh al-Dīn. The force in question turned back after advancing no further than half of the distance between Tripoli and Suwayqa.$^{75}$ It seems that the Almohads, preoccupied as they were with the jihād in al-Andalus, had no appetite for serious warfare on their eastern frontier. There can be little doubt that Salāh al-Dīn and the Ayyubids were the aggressors in Ifrieiya while the Almohad response was late in coming and purely defensive.

We believe that the Ayyubid invasion of Libya and the west was closely linked to Egypt's economic condition in the 1170s. It has been demonstrated by Ehrenkreutz that during Șalāḥ al-Dīn's reign Egypt suffered from an unprecedented shortage of gold. ${ }^{76}$ While the Fatimids consistently issued gold dinars of high purity and regulated the weight of their coins until the very end of their dynasty, Șalāh al-Dīn deliberately debased his dinars and he lifted controls on their weight which fluctuated wildly. He also implemented the switch to a silver standard so that the silver dirham replaced the gold dinar as the unit of official record-keeping (though the dirhams in circulation during this period p. 311 .

${ }^{72}$ Mūsā, al-Nashāṭ al-iqtiṣādì fì l-Maghrib al-islāmì khilāl al-qarn al-sādis al-hijrī,

${ }^{73}$ Ibn Taqī al-Dīn, Midmār , pp. 68-70.

${ }^{74}$ Al-Tijānì, Rihla, p. 243.

${ }^{75}$ Ibn 'Idhārī, al-Bayān, p. 248.

${ }^{76}$ Ehrenkreutz, "The Crisis of Dīnār in the Egypt of Saladin," pp. 178-84. 
were often heavily debased as well). ${ }^{77}$ In his treatise on the history of coinage al-Maqrìzì quotes a passage from al-Qādị al-Fādil in which the latter laments the shortage of gold and silver in Șalāh al-Dīn's Egypt: "...gold and silver left the country without returning and they were nowhere to be found; the people were driven mad by their distress and it came to pass that when a pure dinar was mentioned [to a man] it was as if his wife had been mentioned and if such a dinar ended up in his possession it was as if the tidings of heaven had reached him." $" 78$

There are a number of likely causes for this shortage of precious metals in Egypt. Certainly the chaos and strife which marked the last years of the Fatimid Caliphate as a result of internal civil wars and the repeated assaults of the Crusaders had taken a toll on Egypt's economy. Șalāh al-Dīn's continuous wars with the Crusaders as well as with various Muslim rivals in Bilād al-Shām meant that he was always in need of ready cash, a factor which no doubt contributed to the massive outflow of wealth from Egypt during this period. Perhaps most importantly, the gold mines of Wādī al- Allāqī, located in south eastern Egypt between the Nile Valley and the Red Sea, which had supplied much of Egypt's gold requirements under previous dynasties, had gradually fallen out of production. ${ }^{79}$ Ayyubid campaigns against Nubia and the pro-Fatimid ruler of Aswan, who was known as the Kanz al-Dawla, in the 1170s coupled with Arab revolts in Upper Egypt may have contributed to the instability of the mining region. ${ }^{80}$ In light of these difficulties we can surmise that the Ayyubid invasion of the Maghrib was motivated by a desire to gain access to alternative sources of gold.

Of course the most important sources of gold for the Old World economy prior to the conquest of the Americas lay in West Africa. The gold was transported across the Sahara to the ports and markets of the Mediterranean coast. The trans-Saharan routes of this period can be broadly divided into three major "axes": the western axis with a southern terminus in Awdaghust and a northern terminus in Sijilmāsa; a central axis which ran from the bend of the Niger River near Jenne to

${ }_{77}$ Eddé, Saladin, pp. 492-95.

78 Al-Maqrīzī, al-Nuqūd al-qadìma al-islāmīya, p. 170.

79 Hasan, The Arabs and the Sudan: From the Seventh to the Sixteenth Century, pp. 58-59; Rabie, The Financial System of Egypt: A.H. 564-741/A.D. 1169-1341, p. 169.

${ }^{80}$ Ibn al-Athìr, al-Kāmil, vol. 10, pp. 64-65; Abū Shāma, Kitāb al-Rawḍatayn, vol. 2, pp. 221-22; al-Maqrīzī, al-Sulūk, vol.1, p. 167. 
Tadmakka, Wargla, and finally to Bijāya on the Mediterranean coast; an eastern axis which connected the kingdom of Kanem in Chad to Tripoli or the Jarīd via Zawila in Fezzan. ${ }^{81}$

There were a few major gold fields in West Africa that were exploited during the medieval period. Bambuk, lying south of the Senegal River, and Bure, located on the Upper Niger, supplied most of the gold that was exported north along the western Awdaghust-Sijilmāsa axis, to which they were closest. Further east there were gold mines in the regions of Lobi and Akanland in what is today the modern state of Ghana. There are also gold deposits near Ife (located in southern Nigeria), which was already the seat of an organized state with an advanced culture before the end of the first millennium A.D. ${ }^{82}$

Some scholars believe that the mines located east of Bambuk and Bure were only exploited at a relatively late date with the implication that during the Fatimid, Almoravid, and Almohad periods the great bulk of the gold trade occurred along the western Awdaghust-Sijilmāsa axis. For instance, in his magisterial survey of the medieval trans-Saharan trade Devisse makes no mention of gold production in the eastern sites and he assumes that the movement of gold along the central and eastern axes was limited in comparison with the western axis at least down to the end of the Almohad period. ${ }^{83}$ Austen says that along the route which connected Kanem-Bornu (Chad) to the Libyan oases "gold had never been the major item of trade" ${ }^{84}$

There is a growing amount of evidence, however, which indicates that the eastern sources of gold were being exploited by at least as early as the twelfth and thirteenth centuries, the period with which we are concerned. Sutton makes the case that around roughly 1200 A.D. the Yoruba of Ife were trading gold from their local mines with the Saharan merchants who supplied them with salt, horses, brass, copper, and textiles in return. ${ }^{85}$ McIntosh argues that the fabled West

${ }^{81}$ I have followed the division of the Trans-Saharan routes employed in Vanacker, "Géographie économique de l'Afrique du Nord selon les auteurs arabes de IXe siècle au milieu du XIIe siècle."

82 Shaw, "The Guinea Zone: General Situation."

${ }^{83}$ Devisse, "Routes de commerce et échanges en Afrique Occidentale en relation avec la Mediterranée: Un essai sur le commerce Africain medieval du XIe au XVIe siècle."

${ }^{84}$ Austen, African Economic History, p. 39.

${ }^{85}$ Sutton, "The African Lords of the Intercontinental Gold Trade Before the Black Death: Al-Hasan bin Sulaiman of Kilwa and Mansa Musa of Mali," pp. 224-28. 
African "Gold Island" known as Wangara, which is mentioned by the Arab geographers including al-Idrīsī and often assumed to be a reference to Bambuk or Bure if not an altogether mythical place, should be identified with the lands lying south of the Niger River Bend (the so-called Inner Niger Delta). ${ }^{86}$ She suggests that as early as 1000 A.D. gold from Lobi was traded here. Garrard suggests that exploitation of the Ife and Lobi mines began even earlier in the fifth and sixth centuries A.D. ${ }^{87}$

Of course if the eastern sources of gold were being exploited then it follows that gold from these regions was transported across the Sahara along the eastern and central trans-Saharan routes which were much closer to these sources than the western Awdaghust-Sijilmāsa route. Recent excavations at Tadmakka, a major hub on the central trans-Saharan axis, have confirmed that there was already a vigorous gold trade in that oasis town by the close of the ninth century A.D. ${ }^{88}$ Gold coin moulds which date from this period were discovered at the site. $^{89}$

There is also numismatic and textual evidence for the existence of a considerable gold trade in Zawila, the most important station on the eastern trans-Saharan axis and the busiest market in the Libyan Sahara during the eleventh and twelfth centuries A.D. Archeologists have discovered gold dinars minted in Zawila by the Banū al-Khaț̣āb, the dynasty which ruled the oasis until its conquest by Qarāqūsh. ${ }^{90}$ A passage

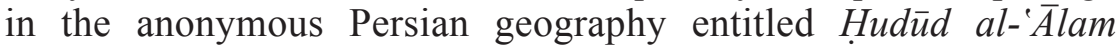
(372/982) states that Zawila was inhabited by Berbers who were rich in gold. ${ }^{91}$ Most importantly, there is the testimony of the famous traveler Benjamin of Tudela who visited Cairo sometime between 1160 and 1173 A.D., making his account particularly valuable for us as this period coincides with the establishment of Șalāḥ al-Dīn in Egypt. ${ }^{92} \mathrm{He}$

${ }^{86}$ McIntosh, "A Reconsideration of Wangara/Palolus, Island of Gold."

87 Garrard, "Myth and Metrology: The Early Trans-Saharan Gold Trade."

${ }^{88}$ Nixon, "Excavating Essouk-Tadmakka (Mali): New Archaeological Investigations of early Islamic trans-Saharan trade."

89 Nixon, "Excavating Essouk-Tadmakka," pp. 251-52.

90 Al-Barghūthī, Tārîkh Lì̄bìyā al-islāmì min al-fath al-islāmì hattā bidāyat al-'aṣr al-'uthmānī, p. 260.

${ }^{91}$ Hudūd al-'àlam min al-Mashriq ilā al-Maghrib, al-Hādī (ed.), p. 133.

${ }_{92}$ Benjamin of Tudela, The Itinerary of Benjamin of Tudela, pp. 68-69; Hess, "The Itinerary of Benjamin of Tudela: A Twelfth Century Jewish Description of North-East Africa." 
reports that caravans routinely set out from Helwan for Zawìla. According to Benjamin the caravans brought copper, grain, salt, fruits, and legumes to Zawila and they returned to Egypt with gold and precious stones.

It is interesting that Benjamin makes no mention of slaves coming from Zawila at this time. Zawìla was such an important supplier of black slave-soldiers (who originated in Kanem and neighboring lands) to the Fatimids that these troops were collectively referred to as the $\mathrm{Za}$ willa. ${ }^{93}$ Bovill says that "although the Fezzan-Kawar road carried a great deal of salt southwards from Bilma, it was essentially a slave route". ${ }^{44}$ We can safely rule out the possibility that Șalāh al-Dīn had any interest in acquiring black slaves from Zawilla. The black troops had opposed him most bitterly during the uprising of 562/1169 and as a result he had ruthlessly purged them from the military and the palace administration. Unlike the previous rulers of Egypt Șalāh al-Dīn never employed black soldiers; instead he relied almost exclusively on Kurdish and Turkish recruits. ${ }^{95}$

In a recent study Benhsain-Mesmoudi, Doménech-Belda and Guichard have estimated the theoretical weight of gold minted in each year under the Almoravids and Almohads through analysis of surviving dinars. ${ }^{96}$ From a high average weight of 629 kilograms per year during the reign of 'Abd al-Mu'min (524/1147-558/1163) the amount of gold minted fell to averages of well below 100 kilograms per year during the caliphates of al-Manșūr, al-Nāșir, and Yūsuf II al-Mustanșir (whose reigns cover the period between 580/1184 and 620/1224) before slowly rising again in the last decades of the Almohad period. ${ }^{97}$ The period of the lowest average weight of minted gold (580/1184-620/1224) corresponds to the years when Ifrìiya and in particular the trans-Saharan trade routes passing through the Jarid, were under the control of first Qarāqūsh and then Yahyāa b. Ghāniya. It is possible, as Guichard spec-

${ }^{93}$ Beshir, "Fatimid Military Organization," p. 40.

${ }_{94}$ Bovill, The Golden Trade of the Moors, p. 245.

95 Bacharach, "African Military Slaves in the Middle East: The Cases of Iraq (869955) and Egypt (868-1171)," pp. 487-89.

${ }^{96}$ Benhsain-Mesmoudi, Doménech-Belda and Guichard, "Biens sultaniens, fiscalité et monnaie a l'époque Almohade."

${ }_{97}$ Benhsain-Mesmoudi, Doménech-Belda and Guichard, "Biens sultaniens," vol. 2, p. 615 (chart). 
ulates, that the loss of these routes caused a sharp reduction in the amount of African gold that reached the Almohads during these years. ${ }^{98}$ If this supposition is correct it would be further evidence that the great struggle in Ifrīqiya between Qarāqūsh, the Banū Ghāniya, and the Almohads was in part related to control of the trans-Saharan gold trade.

Though we believe that obtaining access to West African gold was the principle objective of the Ayyubids in the west, it is likely that there were secondary attractions in this region as well. Tribute was levied from the defeated Arab and Berber tribes. The oases were rich in dates and other fruits..$^{99}$ And we must not forget that the Libyan mountain ranges -Jabal al-Akhḍar in Cyrenaica and Jabal Nafüsa in Tripolitania- had forests which could provide the timber and pitch required by the Egyptian naval arsenals.

In this article we have shown that the expeditions to Libya and Almohad Ifrīqiya by Sharaf al-Dīn Qarāqūsh and Ibn Qarātikīn in the 1170 s and 1180s were directed and supported by Șalāh al-Dīn himself, thus they should be regarded as Ayyubid military expeditions rather than the actions of some disobedient officers and men who deserted from the Ayyubid army in Egypt. Then we established that there was a significant gold trade along the eastern and central trans-Saharan axes at this time while Ayyubid Egypt suffered from an unprecedented shortage of the precious metal. We showed that Șalāh al-Dīn had no interest in acquiring black slaves from Zawila because of the peculiar military and political conditions of his reign. We reached the conclusion that the Ayyubid invasion of the Libyan oases and Ifrìqiya was motivated in large part by a desire on the part of Salāh al-Din and his advisors to establish control over the northern termini of the eastern and central Saharan trade routes in order to have access to West African gold and thereby compensate for the Egyptian gold shortage.

${ }^{98}$ Benhsain-Mesmoudi, Doménech-Belda and Guichard, "Biens sultaniens," vol. 2, p. 610 .

99 Eddé, Saladin, pp. 107-108; Thiry, "L’Égypte et le déclin de l'Afrique du Nord," pp. 242-43. Map 1: The Medieval Libyan Sahara. 


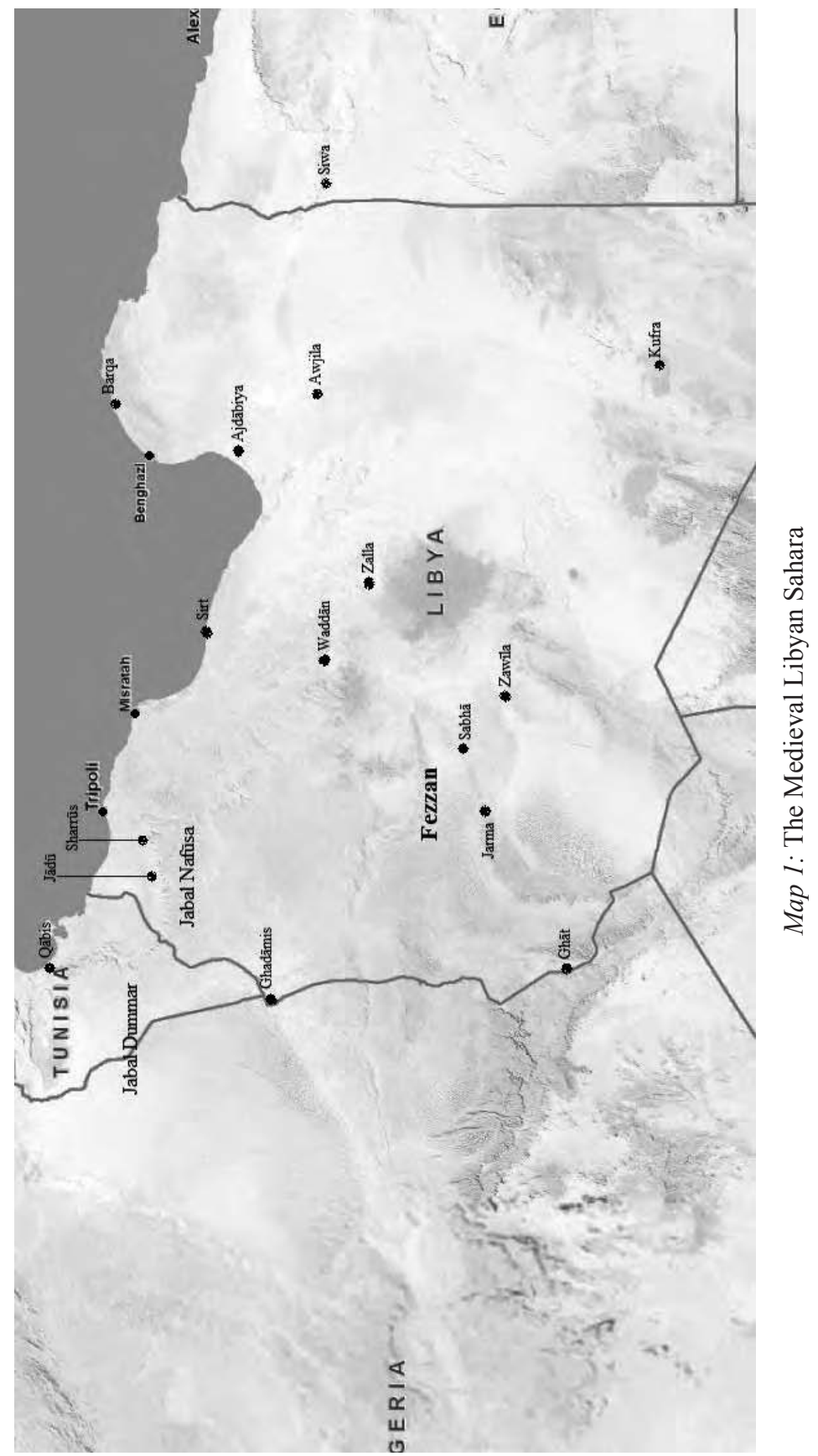

Al-Qanțara XXXIV 2, 2013, pp. 267-295 ISSN 0211-3589 doi: 10.3989/alqantara.2013.010 


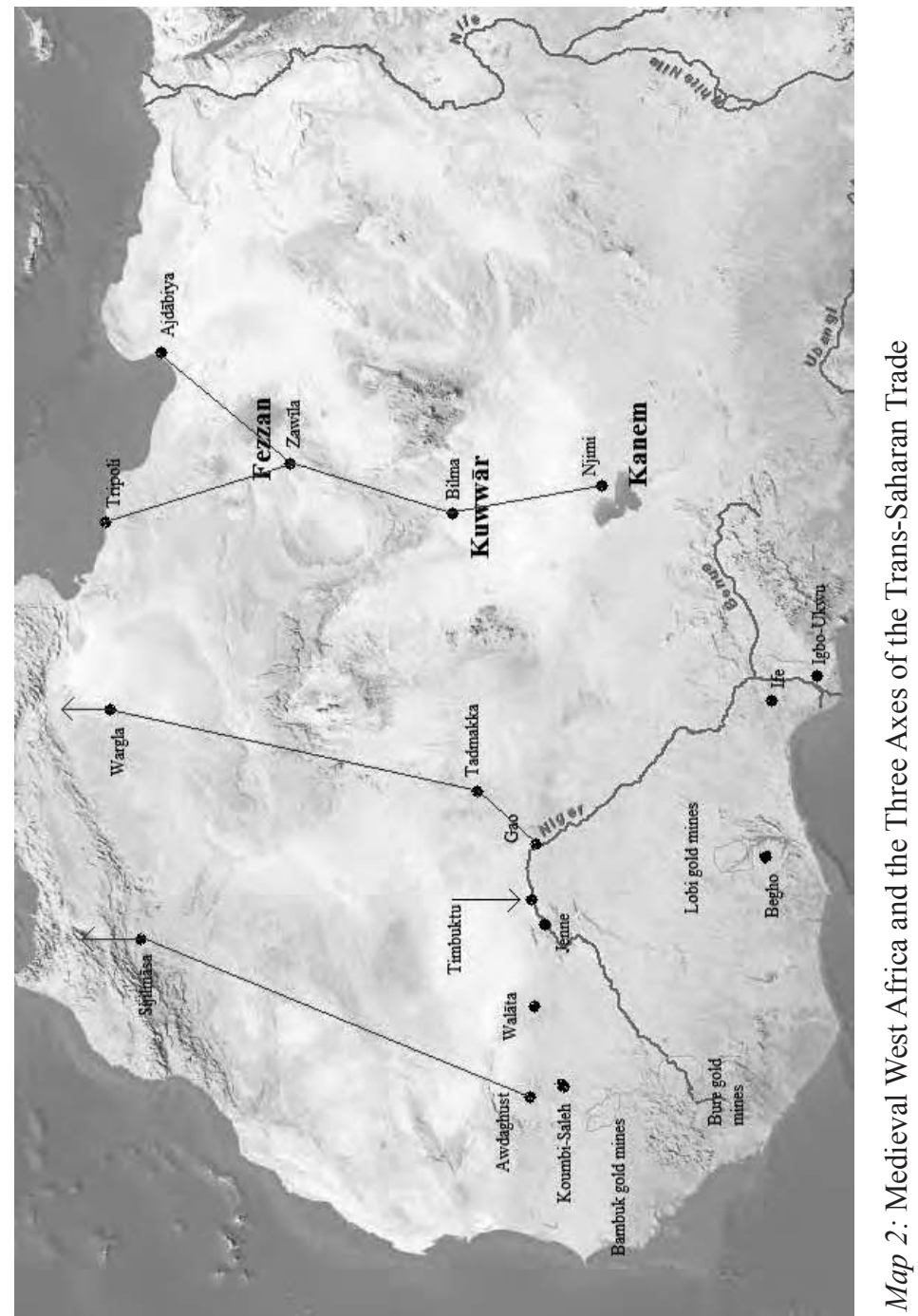

Al-Qantara XXXIV 2, 2013, pp. 267-295 ISSN 0211-3589 doi: 10.3989/alqantara.2013.010 


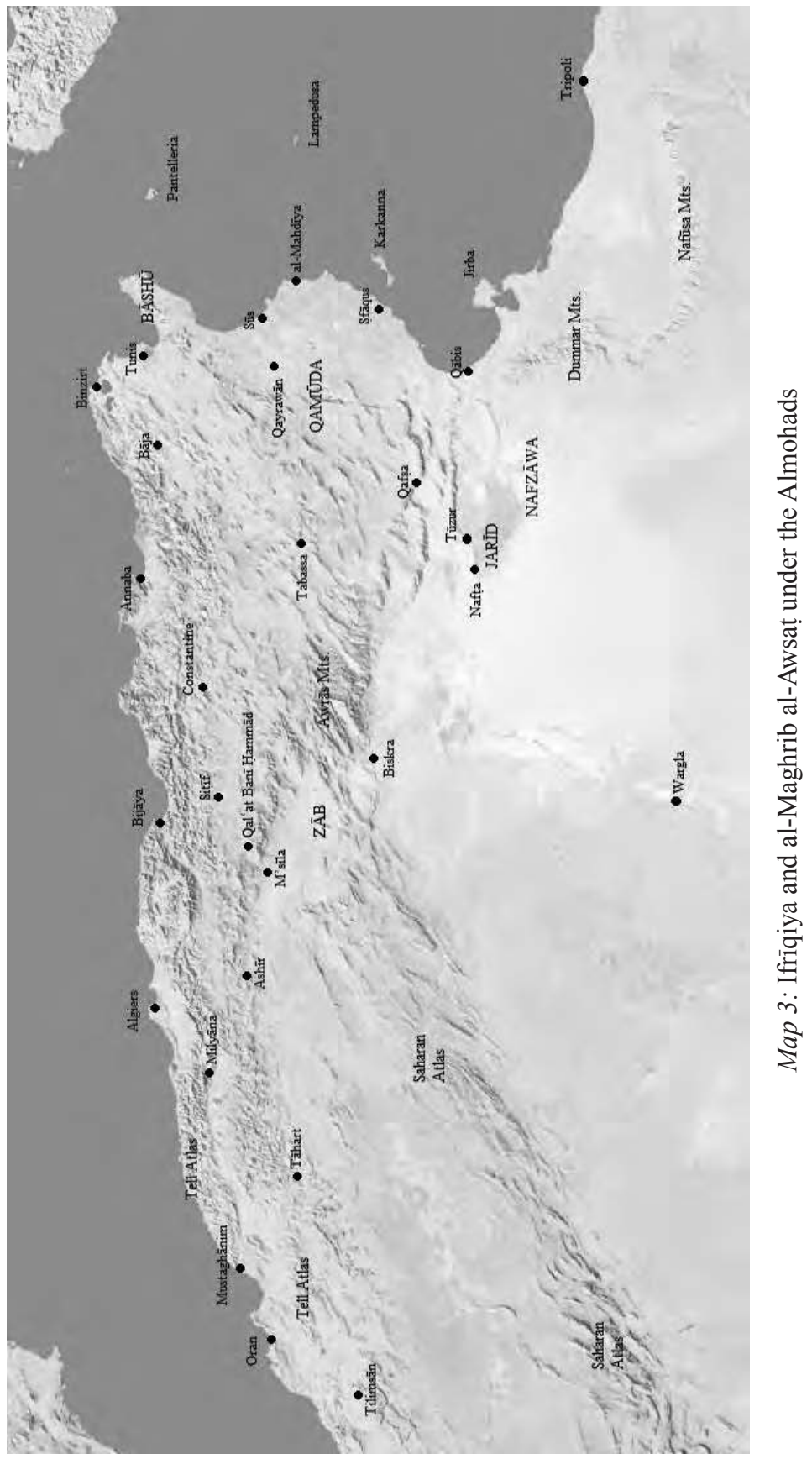

Al-Qanțara XXXIV 2, 2013, pp. 267-295 ISSN 0211-3589 doi: 10.3989/alqantara.2013.010 


\section{Bibliography}

Abū Shāma, Shihāb al-Dīn 'Abd al-Raḥmān b. Ismāeîl b. Ibrāhīm al-Maqdīsī, Kitāb al-Rawḍatayn fi akhbār al-dawlatayn, Ibrāhīm Shams al-Dīn (ed.), Beirut, Dār al-Kutub al-'Ilmìya, 2002, 5 vols.

Abū Shāma, Shihāb al-Dīn 'Abd al-Raḥmān b. Ismāeīl b. Ibrāhīm al-Maqdīsī, Kitāb al-Rawḍtayn fi akhbār al-dawlatayn, Beirut, Dār al Jīl, n.d., reprint of Wādī al-Nìl edition, 1871.

Austen, Ralph A., African Economic History, Portsmouth New Hampshire, Heinemann Educational Books, 1987.

Bacharach, Jere L., "African Military Slaves in the Middle East: The Cases of Iraq (869-955) and Egypt (868-1171)," International Journal of Middle East Studies, 13, 4 (1981), pp. 471-95.

Al-Barghūthī, 'Abd al-Lațîf Maḥmūd, Tārìkh Lìbìyā al-islāmì min al-fath al-islāmī ḥattā bidāyat al-'aṣr al- 'uthmānī, Beirut, Dār Șādir, 1973.

Bel, A., Les Benou Ghânya, Paris, E. Leroux, 1903.

Benhsain-Mesmoudi, R., Doménech-Belda, C. and Guichard, P., "Biens sultaniens, fiscalité et monnaie a l'époque Almohade," in Patrice Cressier, Maribel Fierro and Luis Molina (eds.), Los Almohades: problemas y perspectivas, Madrid, CSIC, 2005, vol. 2, pp. 585-615.

Benjamin of Tudela, The Itinerary of Benjamin of Tudela, Marcus Nathan Adler (ed. and transl.), London, Oxford Univ. Press, 1907.

Beshir, B.J., "Fatimid Military Organization," Der Islam, 55 (1978), pp. 37-56.

Bovill, E.W., The Golden Trade of the Moors, London, Oxford Univ. Press, 1968.

Broadhurst, Roland J.C., The Travels of Ibn Jubayr: a Medieval Spanish Muslim Visits Makkah, Madinah, Cities of the Middle East and Sicily, London, Camelot Press, 1952, reprinted in New Delhi by Goodword Books, 2003.

Devisse, Jean, "Routes de commerce et échanges en Afrique Occidentale en relation avec la Mediterranée: Un essai sur le commerce Africain medieval du XIe au XVIe siècle," Revue d'Histoire Économique et Sociale, 50, 1 (1972), pp. 42-71.

Eddé, Anne-Marie, Saladin, Paris, Flammarion, 2009.

Ehrenkreutz, Andrew S., Saladin, Albany, SUNY Press, 1972.

Ehrenkreutz, Andrew S., "The Crisis of Dīnār in the Egypt of Saladin," Journal of the American Oriental Society, 76 (1956), pp. 178-84.

Ehrenkreutz, Andrew S., "The Place of Saladin in Mediterranean Naval History," Journal of the American Oriental Society, 75, 2 (1955), pp. 100-116.

Garrard, Timothy F., "Myth and Metrology: The Early Trans-Saharan Gold Trade," Journal of African History, 23, 4 (1982), pp. 443-61.

Gaudefroy-Demombynes, M., "Une lettre de Saladin au calife almohade," in Mélanges René Basset, Paris, E. Leroux, 1925, vol. 2, pp. 279-304.

Al-Ghannāy, Marāji 'Aqīla, Suqūt dawlat al-Muwahhidìn, Benghazi, Manshūrāt Jāmi at Qār Yūnis, 1988. 
Hasan, Yūsuf Fadll, The Arabs and the Sudan: From the Seventh to the Sixteenth Century, Edinburgh, Edinburgh University Press, 1967.

Hess, Robert L., "The Itinerary of Benjamin of Tudela: A Twelfth Century Jewish Description of North-East Africa," Journal of African History, 6, 1 (1965), pp. 15-24.

Al-Himyarī, Muhammad Ibn 'Abd al-Mun im, al-Rawd al-mi tạar fi khabar alaqtāar, Iḥsān 'Abbās (ed.), Beirut, Maktabat Lubnān, 1984.

Hudūd al- '̇̀lam min al-Mashriq ilā al-Maghrib, Yūsuf al-Hādī (ed. and Arabic transl.), Cairo, al-Dār al-Thaqāfìya li-l-Nashr, 1999.

Huici Miranda, Ambrosio, Historia política del Imperio Almohade, Tetuan, Editora Marroquí, 1956-57, 2 vols.

Ibn al-Athīr, 'Izz al-Dīn Abū 1-Hasan, al-Kāmil fì l-tārìkh, Abū 1-Fidā' 'Abdallāh al-Qāḍī (ed.), Beirut, Dār al-Kutub al-'Ilmīya, 1987, 11 vols.

Ibn Ghalbūn, Abū 'Abdallāh b. Khalīl, al-Tadhkār fi man malaka Ṭarāblūs wamā kāna bihā min al-akhbār, Ayman al-Buhayrī (ed.), Beirut, Mu'assasat alKutub al-Thaqāfiya,1998.

Ibn 'Idhārī, Abū l-'Abbās Aḥmad b. Muhammad, al-Bayān al-mughrib fì akhbār al-Maghrib wa-l-Andalus: qism al-Muwahhịì̄n, M.I. al-Kattān̄̄, M. Ibn Tāwìt, A. Zammāma and M. Zunaybar (eds.), Beirut, Dār al-Gharb al-Islāmī, 1985.

Ibn Jubayr, Muḥammad b. Aḥmad, Riḥlat Ibn Jubayr, Beirut, Dār Ṣādir, n.d.

Ibn Khaldūn, 'Abd al-Raḥmān b. Muhammad, al-'Ibar wa-dīwān al-mubtada'wal-khabar, K. Shahāda and S. Zakkār (eds.), Beirut, Dār al-Fikr, 2001, 8 vols.

Ibn Taghrībirdī, Jamāl al-Dīn Abū l-Mahāsin Yūsuf, al-Nujūm al-zāhira fì mulūk Miṣr wa-l-Qāhira, Cairo, Dār al-Kutub wa-l-Wathā'iq al-Qawmìya, 2005-, 16 vols.

Ibn Taqī al-Dīn 'Umar b. Shāhanshāh al-Ayyūbī, al-Malik al-Manșūr Muhammad, Midmār al-haqā'iq wa-sirr al-khalā'iq, Hasan Habashī (ed.), Cairo, 'Ālam al-Kutub, 1968.

Ibn Wāṣil, Jamāl al-Dīn Muḥammad b. Sālim, Mufarrij al-kurūb fì akhbār Ban̄̄ Ayyūb, Jamāl al-Dīn al-Shayyāl (ed.), Cairo, Wizārat al-Thaqāfa wa-l-Irshād al-Qawmī, 1953, 5 vols.

'Inān, Muḥammad 'Abdallāh, Dawlat al-islām fì l-Andalus: 'aṣr al-Murābițīn wa-l-Muwahhidìn fi l-Maghrib wa-l-Andalus, Cairo, Lajnat al-Ta'ālīf, 1964, 2 vols.

Khalaf Allāh, Ibtisām Marè ${ }^{2}$ al-'Alāqāt bayna l-khilāfa al-Muwaḥhidīya wa-lMashriq al-Islāmī: 1130-1529 A.D./524-936 A.H., Cairo, Dār al-Ma ārif, 1980.

Lev, Yaacov, Saladin in Egypt, Leiden, Brill, 1999.

Al-Maqrīzī, Taqī al-Dīn, Itti' āz al-hunafà'bi-akhbār al-a 'imma al-Fātimìììn alkhulafā', Jamāl al-Dīn al-Shayyāl (ed.), Cairo, Lajnat Ihyā̄' al-Turāth al-Islāmī, 1967-73, 3 vols. 
Al-Maqrīzì, Taqī al-Dīn, al-Nuqūd al-qadìma al-islāmìya, in R. al-Badrī and A. Qāsim (eds.), Rasā'il al-Maqrīzī, Cairo, Dār al-Hadīth, 1998.

Al-Maqrīzī, Taqī al-Dīn, al-Sulūk li-ma'rifat duwal al-mulūk, Muḥammad 'Abd al-Qādir 'Atțā' (ed.), Beirut, Dār al-Kutub al-'Ilmīya, 1997, 8 vols.

Al-Marrākushī, 'Abd al-Wāḥid, al-Mu'jib fi talkhīs akhbār al-Maghrib, Muḥammad Sa īd al-'Aryān (ed.), Cairo, Lajnat Ihyyā' al-Turāth al-Islāmī, 1962.

McIntosh, Susan Keech, "A Reconsideration of Wangara/Palolus, Island of Gold," Journal of African History, 22 (1981), pp. 145-58.

Mouton, Jean-Michel, "La conquête de la Cyrénaïque et de la Tripolitaine par Qarâqûsh: initiative individuelle ou enterprise d'état?," in C. Chanson-Jabeur et al. (eds.) Aux rivages des Syrtes: la Libye, espace et développement de l'Antiquité à nos jours: colloque du 25-26 octobre 1999, Paris, Centre des Hautes Études sur l'Afrique et l'Asie Modernes, 2000, pp. 59-69.

Mūsā, 'Izz al-Dīn 'Umar Aḥmad, Dirāsāt fi tārìkh al-Maghrib al-Islāmī, Beirut, Dār al-Shurūq, 1983.

Mūsā, 'Izz al-Dīn 'Umar Aḥmad, al-Nashāt al-Iqtiṣādì fì l-Maghrib al-Islāmī khilāl al-Qarn al-Sādis al-Hijrī, Beirut, Dār al-Shurūq, 1983.

Muștafā, Shākir, al-Tārīkh al- 'arabī wa-l-mu'arrikhūn, Beirut, Dār al-`Ilm li-1Malāyīn, 1979, 4 vols.

Nixon, Sam, "Excavating Essouk-Tadmakka (Mali): New Archaeological Investigations of early Islamic trans-Saharan trade," Azania: Archaeological Research in Africa, 44, 2 (2009), pp. 217-255.

Al-Qalqashandī, Abū l-'Abbās Aḥmad, Șubḥ al-A 'shā, Cairo, Dār al-Kutub alMișriya, 1922, 14 vols.

Rabie, Hassanein, The Financial System of Egypt: A.H. 564-741/A.D. 1169-1341, London, Oxford University Press, 1972.

Al-Sāḥilī, Na īma 'Abd al-Salām, al-Tawajjuhāt al-siyāsīya li-l-dawla al-Ayyūbìya al-dākhilīya wa-l-khārijīya, Damascus, Dār al-Qutayba, 2009.

Shaw, Thurstan, "The Guinea Zone: General Situation," in UNESCO General History of Africa, M. el-Fasi (ed.), Berkeley, Univ. of California Press, 1988, vol. 3, pp. 461-87.

Sutton, J.E.G, "The African Lords of the Intercontinental Gold Trade Before the Black Death: Al-Hasan bin Sulaiman of Kilwa and Mansa Musa of Mali," The Antiquaries Journal, 77 (1997), pp. 221-42.

Thiry, Jacques, "L'Égypte et le déclin de l'Afrique du Nord (XIe - XIIe siècles)," in U. Vermeulen and D. De Smet (eds.), Egypt and Syria in the Fatimid, Ayyubid, and Mamluk Eras II, Louvain, Peeters, 1998, pp. 237-48.

Thiry, Jacques, Le Sahara libyen dans l'Afrique du nord médiéval, Leuven, Peeters, 1995.

Al-Tijānī, Abū Muḥammad 'Abdallāh b. Muḥammad b. Aḥmad, Riḥlat al-Tijānn̄, Hasan Ḥusnī A Abd al-Wahhāb (ed.), Tunis, al-Maṭba a al-Rasmīya, 1958. 
Vanacker, Claudette, "Géographie économique de l'Afrique du Nord selon les auteurs arabes du IXe siècle au milieu du XIIe siècle," Annales ESC, 29, 3 (1973), pp. 659-80.

Recibido: 26/06/2012

Aceptado: 30/01/2013 